\title{
Organic Farming- Complex Realities
}

\author{
Shivakumar Magada* \\ University of Agricultural Sciences, India
}

*Corresponding author: Shivakumar Magada, University of Agricultural Sciences, Professor of Aquatic Biology, College of Fisheries, India

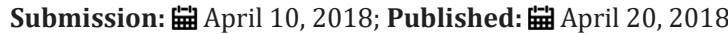

\section{Opinion}

Since the birth of the earth, the whole creation is evolving continuously. Otherwise evolution theory would not have born. But, science is not changing every day; it is our understanding. There was the time when somebody said that earth revolves around the sun, church people did not agree. People were not ready to accept that earth is round. At last, they bowed their heads in front of the science. Our ancients beautifully identified the food crops and taught us cultivation methods in controlled condition. During those days everybody was farmer, everything was organic. The total arable land was sufficient to feed the population of that time.

After the Second World War there was acute shortage of food in many countries. Growing demand for food with increase in population was the challenge to the scientists and the government. Due to the great efforts of scientists, who developed high yielding varieties, hybrids and usage of chemical fertilizers, India became self sustained with regard to food production. It was the need of the country. And now, we have left with no option but using chemical fertilizer and pesticides. We know the recipes of success of green revolution, but now we have to understand the ingredients of disasters of the same too. Food production means not just growing food for ourselves; we have to feed the hungry world. "Future threat to the human kind is not diseases, not war; it is hunger and sheer crush of humanity"-Magada.

There is direct correlation between hunger and humanity. Hunger is biological base for all worlds' problem. World population data sheet says that the Indian population was 1.5 billion in 2050; already it is 1.349 billion. Though, annual food production of India stands about 278 million tons ( $\mathrm{mt}$ ), 20 crores of people die of hunger and $14.5 \%$ of the population is under nourished, 3000 children die every day. Fortunate are those who die of starvation; unfortunate of those who survive starvation. In this context, organic farming has to be viewed critically.

Of course, what is organic? In fact, in the whole universe, everything is inorganic. Air, soil, plant, animals and even human being is inorganic. If you simplify anything, you get either elements or compounds. Whatever the food you ingest, it will be simplified into simpler forms and gets collected and utilized. Protein will become amino acids, complex carbohydrates will become simple sugars and fats will be divided into simple fatty acids. Even plants require the nutrients in the ionic forms. The requirement of the different nutrients by the plants is known scientifically. Irrespective of the origin of the nutrients, plants require certain nutrients which need to be supplied from external source. Only then you get higher yield. Soil is an independent, dynamic inorganic body of nature that acquires properties in accordance with forces which act upon it. Hence the present packages of practice were designed to get more yields. In fact, agronomists have always advocated integrated nutrient management i.e. inclusive of high dose of organic manure. On the other hand, rampant and injudicious usage of many chemicals and pesticides at all levels i.e. from the farm till the produce reaches consumers, many problems have been raised. Foods are contaminated with many toxic chemicals. Infant mortality rate (IMR) is increased significantly. Kids are born with many deformities, new diseases started and spread of disease is faster than ever before. Hence, many realized to go organic.

Organic farming is not a technique; it is a concept or movement. Everyone agree that, it is the solution for the better health and environment. Better health of how many people is the question. To save future, people realized that organic farming is the solution. But it is not so easy to adopt these concepts in a large scale. Because it raises many complex issues like yield reduction, food shortage, increased food cost, uneven distribution and hence causing social disparity. Is India ready to take up these challenges raised by the organic farming? In the present context, organic farming is an absurd concept but it has complex truth for the future. So, it is referred as paradox in this text.

This is where scientists, farmers and policy makers should join together and understand the paradoxes of organic farming without any prejudices. On the other hand, scientists have to critically analyze the quantity of nutrients required by the plant, methods of application of chemical fertilizers, so that there will be minimal quantities of residue gets into the nature. Careful study on method of absorption \& retention in soil, impact of leaching, percolation, 
surface run off and residual impacts and other subtler issues have to be evaluated thoroughly before advocating the benefits of any chemical. On the other hand promoters of organic farming have to go slow in implementing their ideology, since it is not so easy to adopt these concepts to the staple food crops of India i.e. wheat and rice.

No doubt that organic farming concept can be easily adoptable to perennial crops, horticultural crops and plantation crops. Any fruits or meats that are being used as food cannot substitute wheat or rice. So, the reduction in yields of these subsidiary foods may not make significant difference even there is short of supply. But, people are promoting organic farming for even food crops like wheat and rice. At present sustainable production and soil health are inversely related and it cannot be reversed in a short period or it may not be possible. In the Indian context, the agricultural sector has been an important sector from the point of economic growth. This transition from chemical based agriculture to organic agriculture would depend on how well the Indian government handles this transition period.

An underlying assumption about organic farming in this paper is there would be great imbalance in the market because produce from organic farming cannot be sold at the cheaper rates in the domestic market. It definitely reaches the stomach of small segment of the upper class. And many a times, it is intended or destined to the foreign market. One should be happy, because, at least some of our farmers get better price for their produce. While appreciating the concepts of organic farming, we must learn to understand its impact on local consumers, domestic markets and agro-based industries. The adequate supplies of essential agriculture produce for mass consumption is also a responsibility of the government. So, the impulse of market dynamics may be high during the initial years. Agricultural export may bring good foreign exchange, but micro imbalances in domestic market due to variability in agricultural performances are also important factors.
The links between different sectors with agriculture and their responses need to be thoroughly analyzed and then we must decide the rate of transformation from chemical to organic agriculture. The logical assumptions in this paper might look like it is against the organic farming; but not so. It is a cross sectional approach to understand and educate the people about organic farming. Like sudden stopping of medicines causes some disorders in human beings, sudden withdrawal of chemicals and fertilizers in agriculture also causes imbalance in the total production and productivity.

So, we must withdraw usage of chemicals gradually. We must learn from history, otherwise we become part of it. Already, certifiers of organic farming, marketers, NGOs have established their foot in the movement of organic farming. They must ensure that farmers get the real benefit of organic farming. Otherwise, traders and middlemen will take away the major share without investing the sweat. Marketers should make sure that they really sell organic foods at affordable prices. There are claims that some farmers are getting good yields with organic farming. In this spirit, it is not fare to blame the universities and scientists. Their contributions must be acknowledged. Agricultural Universities have some set systems and protocols to analyze and understand the new issues.

Unless they study systematically for longer period, they cannot jump into any conclusion. Of course, they wish every farmer to get higher yields and better price for their produce. In a large country like India, people do not realize unless there is a strong social problem. Since it is the beginning, it takes some more time to understand the dynamics of organic farming. Till such time researchers, policy makers and economists should not wait. They must be able to understand the possible positive and negative impacts of organic farming with special reference to staple food crops and draw conclusion on the rate and direction at which it should go.

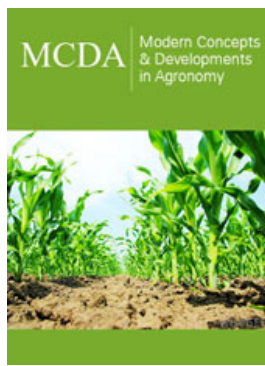

\section{Modern Concepts \& Developments in Agronomy}

\section{Benefits of Publishing with us}

- High-level peer review and editorial services

- Freely accessible online immediately upon publication

- Authors retain the copyright to their work

- Licensing it under a Creative Commons license

- Visibility through different online platforms 